\title{
The Construction of Multi-dimensional Teaching Model for Listening in ESL Class
}

\author{
An Empirical Study
}

\author{
Yu Wang \\ College of Foreign Studies \\ Shandong Technology and Business University \\ Yantai, China
}

\begin{abstract}
Listening is crucial to the second language acquisition for students. Due to the relatively unappreciated role of listening in language development, educators and language experts have been actively promoting different methods to enhance listening skills. The advent of advanced web technology has provided more opportunities for teachers and students to expand their teaching and learning scope. With the guidance of metacognition and Zone of Proximal Development theory, this research aims to discuss a new teaching model which blends traditional class, WeChat communication platform and smartphone learning apps to facilitate L2 students in China in learning English listening. The research design is experimental with a t- test to justify its validity. The data collected are positive and suggest this new teaching model is effective in improving students' listening competence.
\end{abstract}

Keywords-listening; autonomous learning; web technology; smartphone apps; wechat

\section{INTRODUCTION}

Within the field of second-language acquisition, the development of oral abilities (listening and speaking) is one of the most challenging and neglected aspects (Vandergrift \& Goh 2012; Graham \& Santos 2015). Listening could be viewed as a crucial language skill which learners of language need to develop. Moreover, all other language skills' development becomes interwoven with listening skills.

Chinese scholar, Shu Dingfang (2006) has pointed out that traditional teaching model in China's higher education has been teacher-centered and examination-oriented, which has resulted in insufficient language input for students and misconception of learning methods. As for listening class, these problems are even more prominent. In some universities, due to curriculum reform in higher education, English-major students only have two periods of listening class each week. Thus, for Chinese students, especially college students majoring in English, listening has always been a bottleneck, which has directly hindered their English competence development.

With new technologies' appearance, including their influence on people's life aspects and education, language learning and teaching seems to have entered a new area. The use of multimedia tools in order for the design and development of language acquisition materials has been a matter of urgency of teachers today.

College English curriculum teaching requirements (Trial) issued in 2007 by China's Education Department, says: "we should make fully use of the opportunities brought by the development of multimedia and network technologies to adopt a new teaching model to replace the traditional teacher-centered one."

Mobile technologies have the potential to support second language learning, by providing autonomous learning opportunities and access to learning materials (Reinders \& White, 2011). Internet technology has provided an alternative learning space, a different delivery mode to that of the classroom. It provides for blended teaching and learning based on alternating online and offline activities and materials (Tomlinson \& Whittaker 2013).

Researchers recommend that Internet should be maximized because it is a platform that can provide authentic and recent materials pertaining to the target language being studied (Warschauer \& Kern, 2000). The authentic materials provided on internet are more motivating for the learners. Internet materials are considered effective and authentic tools which can help L2 learners successfully apply learning in real-life contexts. Authenticity is essential for transferability to the real world (Porter \& Roberts 1987). Unauthentic dialogues do not prepare learners for realistic communicative events.

Now, as the fast development of network technologies, smartphones have become indispensable in human's life. Meanwhile, they are potentially useful for second language learning and instruction due to their portability and connectivity. In particular, smartphones support mobile applications (apps), which can provide a brand new virtual learning context for autonomous learning, peer collaborative learning and interactive learning between teachers and students. Therefore it is a good try to make fully use of network communication platform (e.g. wechat, qq etc.), English learning apps and classroom to construct a multidimensional listening teaching model in order to convert students' learning concepts, motivate learning interests and 
cultivate their autonomous learning ability so as to achieve the ultimate goal of improving their listening competence.

\section{LITERATURE REVIEW}

"Listening is the process of receiving, constructing meaning form, and responding to spoken and/or nonverbal messages" (Emmert, 1994), which is a complex cognitive, psychological, and behavioral activity. Therefore, development of listening competence requires a systematic, developmental approach; opportunities for listening practice in varied contexts and for different purposes; multiple opportunities for self-assessment and feedback; and goalsetting. All of these belong to metacognition, which refers to higher order thinking that involves active control over the cognitive processes engaged in learning. Metacognition strategies are used by L2 learners to increase their comprehension and L2 retention, and include planning, monitoring, evaluating and problem-solving; and these strategies help learners "manage themselves as learners, the general learning process, and specific learning tasks" (Oxford, 2001, 167).

With the development of metacognitive strategy research in the 1950s, autonomous learning has been considered as an important research topic in education psychology. Cultivation of autonomous learning ability of students has been recognized as the ultimate goal of education (Wang, 2002).

"The advent of Web 2.0 has enhanced students' participation, autonomy and independent learning by generating a collaborative approach based on user's willingness to create and share knowledge, information and user-generated resources within different types of communities" (Plutino, 2017). "The key idea in the learningcommunities approach is to advance the collective knowledge of the community, and in that way to help individual students learn" (Bielaczyc \& Collins, 1999, 19). This is supported by Vygotsky, a famous psychologist, who "states that individuals can learn on their own only to a certain extent and it is with guidance from a More Knowledgeable Other (MKO) that each of us can learn more and achieve a higher potential" (Plutino, 2017). He also puts forward the theory of Zone of Proximal Development, stating that "through problem solving under adult guidance or in collaboration with more capable peers" (Vygotsky, 1978), the potential development of leaners could be achieved.

$\mathrm{Hu}$ Zhuanglin (2005) points out that teaching should dedicate to create the zone of proximal development, and try to convert the zone of proximal development into the actual development level, which calls for teachers' guidance and assistance to help students achieve a higher level of development and students' mastery of collaboration and autonomous learning.

Present and previous research concerning Second language listening is plentiful, coming from a variety of researched areas. These areas include Applied Linguistics, Bilingualism, Cognitive Psychology, and Psycholinguistics, although sometimes blurred are the boundaries between these fields, because every one of them stands influenced by the other (Holden, 2004). Many studies have examined the effectiveness of particular multimedia tools in promoting language competence of students. O'Bryan and Hegelheimer (2007) studied how podcasting is an innovative way of teaching language in the classroom. As is shown by the study, the instructors and students all consider podcasting an easy method and a positive tool as well, despite the technical difficulties experienced.

Lee and Lee (2012) specially observed students' preferences for online versus offline listening activities in English as second language at university level. They found that "an optimal design and the successful implementation of the blended learning model in listening instruction require the teacher to play a crucial role as a designer, a selector of effective activities, materials and multimedia tools, and a monitor who provides timely scaffolding".

Vandergrift and Goh (2012) look at research on the use of video, forms of textual support, transcripts and closed captions and state that the value of different media are rather mixed depending on the types of media, method of delivery and their role in the learning context.

Emily Mindog (2016) carries out a research to explore, describe and analyze the utilization of smartphone apps by four Japanese university students to support learning English as a foreign language. This study provides some evidence that apps can support intermediate English language learners by giving them easy access to English content that caters to their interests.

In China, researchers and teachers have also probed into this domain concerning improving listening competence by integrating new media and network (Huang, 2012; Guo, 2013; Gao,2009; Qian, Yuan, Fang, 2010; Yin, Fu, 2007 ). Shu Dingfang (2006) has put forward a macro-concept about constructing a brand new teaching model for foreign language teaching. He has suggested some ideas about the basic functions of classroom teaching: to motivate and sustain students' learning interest; to provide sufficient resources and opportunities for language learning; to teach learning strategies; and to help students resolve difficulties in learning.

Yan Canxun (2005:56-60) has reported a listening teaching research under the network environment in his univerisity, which concludes that network autonomous listening learning is workable. Lin Lilan (2006:39-45) integrates learning strategies into listening learning under the network autonomous learning environment, and finds out that learning strategies training should be introduced in order to improve the effect of network autonomous learning model.

But at present, there is rarely research on the integration of smartphone apps into English listening teaching in China, we know little about to what extent the use of apps can influence students' listening competence and what teachers should do to facilitate students in improving their listening competence. After a thoughtful conception and based on the theories discussed previously, this paper aims to explain how this multi-dimensional listening teaching mode is 
constructed and how students will benefit from it, in hoping to provide some insights into listening teaching reform for ESL class.

\section{RESEARCH DESIGN AND PROCEDURE}

\section{A. Subjects}

A total of 58 sophomores of English major, in two classes, have been chosen as subjects for this research in the spring term, 2017-2018. One class is regarded as the control group, the other as the experimental group.

\section{B. Method and Research Procedure}

The research adopts quantitative and qualitative analysis and class observation. The preconception of this teaching mode is based on the network technology and smartphone apps. The research design goes like this: traditional class, network communication platform (e.g. wechat), and smartphone English learning apps have been integrated to construct a multi-dimensional teaching model for listening. In this teaching model, listening teaching and learning is carried out both inside and outside of the classroom.

At the beginning of this term, I have introduced students in experimental group some English learning apps (Everyday English, BBC, PUT, Kekenet etc.) and learning programs for them to choose to learn after class. In class, listening learning strategies (eg. mental translation, direct attention, problemsolving, planning and evaluation) are introduced to students. Outside of the classroom, the learning proceeds via the usage of various English learning apps on smartphones. And then we use the network communication platform like wechat to set up a wechat learning group to facilitate the communication and interaction between students and teachers. On the other hand, traditional listening teaching model is carried out in control group, with the same metacognitive learning strategies instruction, but without the learning on apps.

Then I ask students in experimental group to listen to English programs every week and they have to upload at least one listening material retelling onto wechat learning group for peer students to listen to and to learn from, and for teacher to check and evaluate. After sixteen learning weeks in this term, each student has uploaded at least 16 listening materials, and interaction on wechat learning group has been going on for the same time span.

\section{Data Collection and Analysis}

Students in two groups have taken a pre-test and post-test, which are of the same difficulty degree. At the end of this term, students in experimental group have also completed a questionnaire about their learning on apps. The data are collected and analyzed by SPSS 17.0.

Data analysis is carried out for three set of statistical data. The first set includes data obtained from pretest of students both in control and experimental groups; the second set is composed of juxtaposed data of posttest scores of the two groups. The third set of data is obtained from the questionnaire done by the experimental group. Analysis of the first set of data aims to demonstrate if there are any significant differences between the two groups before the new teaching model is carried out. The second set of data is conducted to justify the effectiveness of the new teaching model. The third set of data is used for feedback and suggestion of this new teaching model.

\section{Findings and Discussion}

1) Class observation: There is a significant difference between the control group and the experimental group based on the observation in class. Students in experimental group are rather active, and can autonomously complete their learning tasks and set new goals for themselves. Interactions between teacher and students are intense and efficient. Students are keen on asking questions and eager to put the new learnt strategies into use to amplify their learning outcomes. On the contrary, students in control group are rather passive. They only complete the learning tasks on book, and have little interaction with teacher. The atmosphere is quite dull, and students are lack of motivations to broaden their learning.

2) Questionnaire: The questionnaire contains 12 questions, concerning the most frequently used websites and learning apps (Q1-2), the sources of getting to know those apps (Q3), learning preferences and time span each week on apps (Q4-5), the reasons for obstruction and promotion their learning on apps (Q6-7), the benefit of learning listening on apps and wechat group (Q8-10), and suggestions for learning methods and further class instruction (Q11-12).

Students' preferences for English learning websites and apps are quite the same, such as Kekenet (a very popular English learning website and app in China), and VOA, BBC websites and apps. And there are many other apps in the market, the users enjoy great freedom in choosing apps that work for them. Individual language learners can make decisions on what types of apps to use. Not only that, they can also choose the manner (location, frequency, duration) in which the app will be used based on their preferences, goals and everyday life, which is one of the appealing features of this new teaching model.

94\% students have claimed that it is the teacher who guides and recommends them to learn English listening on apps, which has justified the theory of Zone of Proximal Development. Teacher in this model is a More Knowledgeable Other (MKO), who can assist, guide and motivate students to achieve a higher level of development and have effective autonomous learning.

As is shown in "Fig. 1", at least $76 \%$ students can guarantee 1 hour or more learning on apps, which actually extends their listening practice to makeup the limitation of class instruction. 


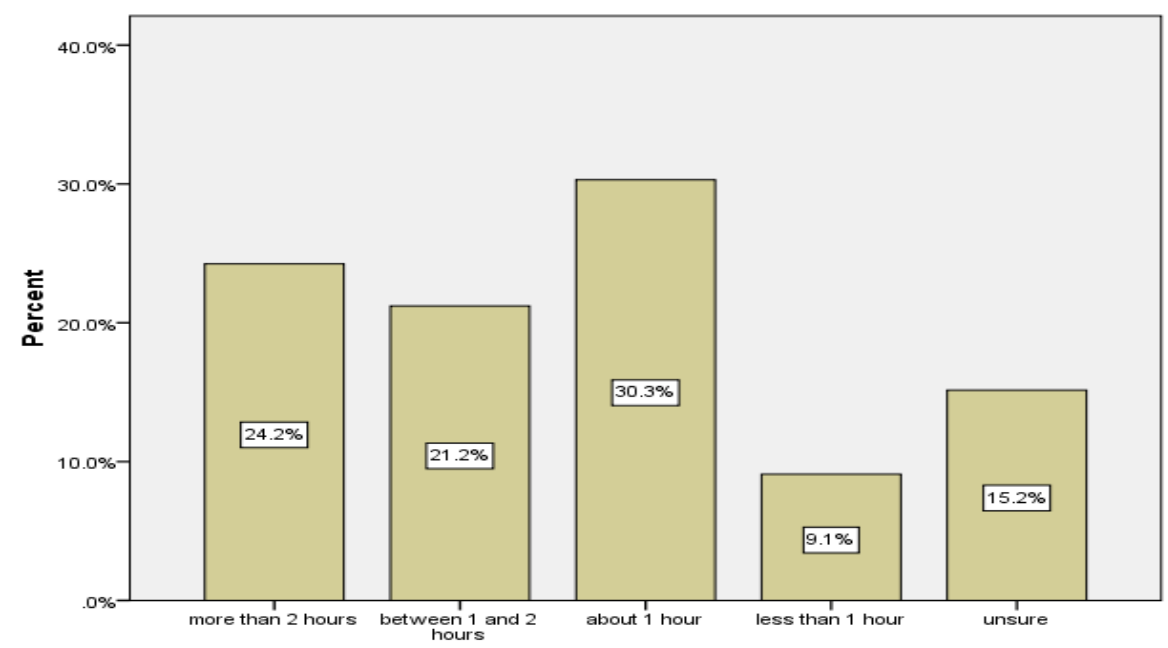

How long do you use English listening apps to learn English each week?

Fig. 1. Learning time span each week.

$52 \%$ students are confused about the complicated and various resources on line, which is the main reason intimidating them from learning on apps. When facing with overabundance of information, some students may difficulty exacting relevant learning materials for efficient learning. And meanwhile this is also an advantage for students to prefer to learn on line. $70 \%$ students are fascinated by the abundant resources on line. On-line resources may be appealing, but that doesn't mean they will autonomously lead to better learning. Students need guidance in navigating the useful and relevant resources available to them from teachers.
Portability and easy-accessibility of smartphones are also good reasons for students to like this new learning model. $67 \%$ students believe that learning on apps can broaden their knowledge and compensate what they cannot learn in class.

We can see clearly from "Fig. 2" and "Fig. 3" that most students hold positive attitudes about learning listening on apps and wechat group. Respectively $85 \%$ and $94 \%$ students believe they have benefited from this new teaching model, which will encourage and inspire me to further implement this practice so as to benefit more students.

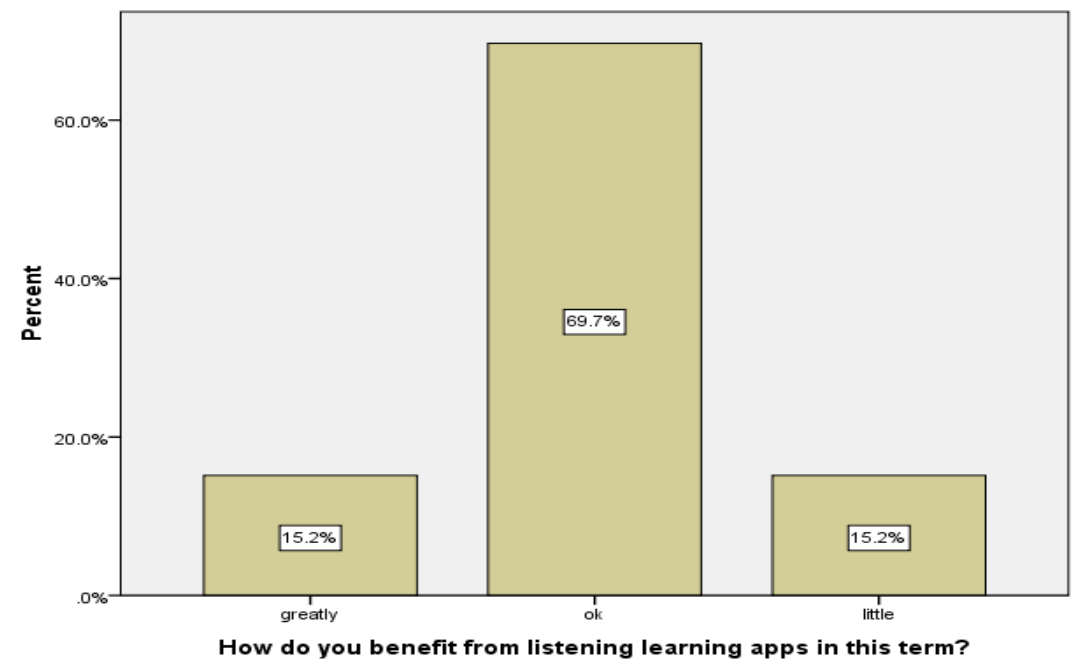

Fig. 2. Benefit from learning on apps. 


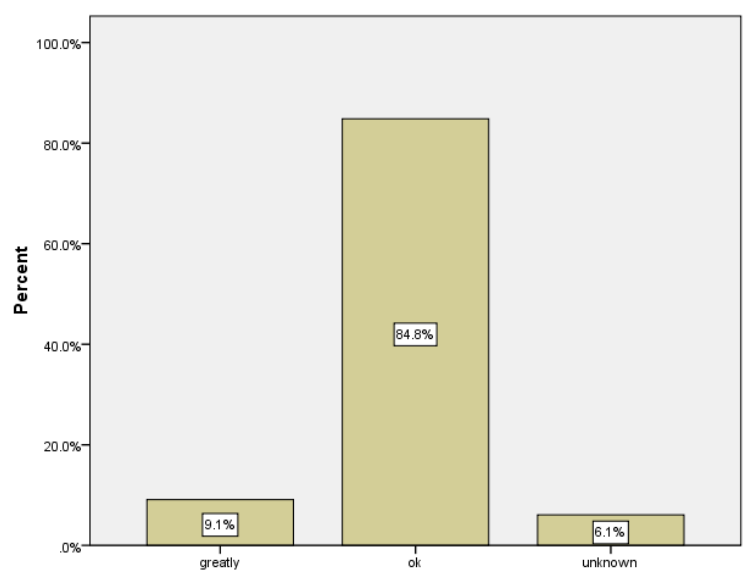

Fig. 3. Benefit from interactive learning on wechat group.

In Q10, a lot of students express that spontaneous and interactive learning on wechat group has improved their listening as well as their oral English level, and through the feedback and surveillance of teacher, they have got more opportunities to correct errors and misunderstandings. What's more, they believe on-line communication platform has offered them a pressure-free space, so they feel at ease to practice their oral English and listening without anxiety.

Questions 11 and 12 are students' suggestions about how to improve their listening competence and how the teachers can deliver class instruction effectively. They have put forward a lot of valuable suggestions which are worthy of considering.

3) Test results: Descriptive data are collected to test validity of the research. According to the result (as is shown in "Table I") of independent samples t-test (pretest result), $\mathrm{P}=0.233>0.05$, there are no significant differences between experimental and control groups at the beginning of the research. That means before this research, students in two classes enjoy the same level in listening competence, which indicates these two groups are comparable.

TABLE I. INDEPENDENT SAMPLES TEST ANALYSIS FOR EXPERIMENTAL AND CONTROL GROUPS

\begin{tabular}{|c|c|c|c|c|c|c|c|c|c|c|}
\hline \multicolumn{11}{|c|}{ Independent Samples Test } \\
\hline & & \multicolumn{9}{|c|}{$\begin{array}{l}\text { Levene's Test for Equalityt-test for Equality of Means } \\
\text { of Variances }\end{array}$} \\
\hline & & \multirow[t]{2}{*}{$\mathrm{F}$} & \multirow[t]{2}{*}{ Sig. } & \multirow[t]{2}{*}{$t$} & \multirow[t]{2}{*}{ df } & \multirow[t]{2}{*}{ Sig. (2-tailed) } & \multirow[t]{2}{*}{$\begin{array}{l}\text { Mean } \\
\text { Difference }\end{array}$} & \multirow[t]{2}{*}{$\begin{array}{l}\text { Std. } \\
\text { Difference }\end{array}$} & \multicolumn{2}{|c|}{$\begin{array}{l}\text { Error } 95 \% \text { Confidence Interval of the } \\
\text { Difference }\end{array}$} \\
\hline & & & & & & & & & Lower & Upper \\
\hline \multirow{2}{*}{ pretest } & Equal variances assumed & 1.456 & .233 & -.213 & 56 & .832 & -.85455 & 4.02118 & -8.90995 & 7.20086 \\
\hline & Equal variances not assumed & & & -.219 & 55.743 & .828 & -.85455 & 3.90366 & -8.67532 & 6.96623 \\
\hline \multirow{2}{*}{ posttest } & Equal variances assumed & .449 & .505 & -2.588 & 56 & .012 & -7.64606 & 2.95401 & -13.56365 & -1.72847 \\
\hline & Equal variances not assumed & & & -2.542 & 47.995 & .014 & -7.64606 & 3.00761 & -13.69329 & -1.59884 \\
\hline
\end{tabular}

After the research, paired samples tests are conducted to examine whether students' listening competence have improved significantly after 4 months' learning. And we can see clearly from "Table II" and "Table III" that the value of

$\mathrm{P}=0.000<0.05$ in both control and experimental groups, that is to say, students in both groups have had a significant improvement in listening competence.

TABLE II. PAIRED SAMPLES TEST FOR CONTROL GROUP

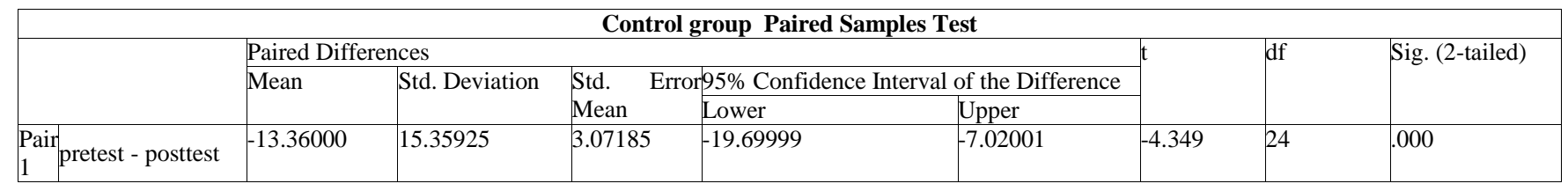

TABLE III. PAIRED SAMPLES TEST FOR EXPERIMENTAL GROUP

\begin{tabular}{|c|c|c|c|c|c|c|c|c|}
\hline \multicolumn{9}{|c|}{ Experimental group Paired Samples Test } \\
\hline & & \multicolumn{4}{|c|}{ Paired Differences } & t & \multirow[t]{3}{*}{ df } & \multirow[t]{3}{*}{ Sig. (2-tailed) } \\
\hline & & Mean & Std. Deviation & Std. Error Mean & $\begin{array}{l}95 \% \text { Confidence Interval of the } \\
\text { Difference }\end{array}$ & & & \\
\hline & & & & & Lower & & & \\
\hline Pair 1 & pretest - posttest & -20.15152 & 16.41097 & 2.85678 & -25.97059 & -7.054 & 32 & .000 \\
\hline
\end{tabular}


The hypothesis of this research is that after instructed in this multi-dimensional teaching model for listening in ESL class, students in experimental group would perform better than that in control group. In order to testify the hypothesis, the posttest data of experimental and control groups were compared using t-test. As we can see from Table 4, the value of $\mathrm{P}=0.012<0.05$ (posttest results), suggests there are significant differences between experimental and control groups in posttest. The hypothesis is justified, which indicates the multi-dimensional teaching model is effective and valid in improving L2 students listening competence.

\section{CONCLUSION}

The outcome of this empirical study concerning the effectiveness of multi-dimensional teaching model is overall very positive. In this new teaching model, students learn to reflect on their performances to determine whether or not his/her listening behaviors are effective. Other students and teacher can also assess his/her performance and provide feedback. Students can learn to recognize, analyze, and address the influences of various listening filters in advance of the listening, and thus foster their self-awareness in the autonomous learning which will benefit them whole life. Listening is dynamic and complex. Using peers' and teacher's feedback and students' own self-assessment, they can establish new goals to keep enhancing listening competence and to refine their listening process.

With the advent of web 2.0 and emerging of learning apps on smartphone, learning on apps can be easy-accessible, effective, and revolutionary. Students have access to the listening materials and tasks in a flexibly way, which maximizes their opportunities for learning. The ability of students' autonomous learning is enhanced thereafter which echoes the ultimate goal of education.

However, the teaching style of education themselves could be a barrier to make use of technology; pedagogical practices must be upgraded and kept flexible by teachers in order not to prevent the learning process from developing. Structural barriers from schools and even the broader educational policy framework can also impede the effectiveness of technology-based listening instruction.

More researches should be conducted to blend web technology to improve other language skills, and the challenges for teachers should be experts both in pedagogy and technology.

\section{REFERENCES}

[1] Bielaczyc, K., \& Collins, A. (1999). Learning communities in classrooms: a reconceptualization of educational practice. In C. M. Reigeluth (Ed.), Instructional Design Theories and Models: A New Paradigm of Instructional Theory, Vol. II. Mahwhah NJ: Lawrence Erlbaum Associates.

[2] Byrne, J., \& Diem, R. (2014). Profiling mobile English language learner. The JALT CALL Journal, 10(1), 3-19.

[3] China's Education Department. (2007). College English curriculum teaching requirements (Trial)
[4] Emily Mindog. (2016). Apps and EFL: a case study on the use of smartphones apps to learn English by four Japanese university students. The JALT CALL Journal, 12(1), 3-22.

[5] Emmert, P. (1994). A definition of listening. Listening Post, 51, 6.

[6] Gao Zhi-dong. (2009), Features of essential factors in college English teaching and shift of teaching models. CAFLEC, 126, 49-52.

[7] Graham, S \& Santos, D (2015). Strategies for second language learning current scenarios and improved pedagogy. Palgrave Macmillan, London.

[8] Guo Zhong-zhuang (2013). On the multimedia-based interactive teaching reform of English listening course. Journal of Shenyang Normal University (Social Science Edition), 2, 93-95.

[9] Holden, W. R. (2004). Facilitating listening comprehension: Acquiring successful strategies. Bulletine of Hukuriku University, 28, 257-266.

[10] Hu Zhuang-lin. (2005). China's English education reform: trends and issues. Foreign Languages in China, 6, 4-10.

[11] Huang, Shu-chun. (2012). Three-dimensional teaching model and construction for listening course of English majors in the context of network. Journal of Inner Mongolia Agricultural University (Social Science Edition), 6, 136-137, 143.

[12] Lee, J \& Lee, C H (2012). Students' perspectives and the effectiveness of blended learning in L2 listening at university level. Multimedia Assisted Language Learning, 151, 59-89.

[13] Lin Li-lan. (2006), Students' learning strategies in the web-based self-assess learning environment: an experiment on English listening instruction. Foreign Language Research, 96(2), 39-45.

[14] Oxford, R. (1990). Language learning strategies: What every teacher should know. Newbury House, New York.

[15] Oxford, R. L. (2001). Language learning strategies. In R. Carter, \& D. Nunan (Eds.), The Cambridge guide to teaching English to speakers of other languages, 166-172. Cambridge University Press.

[16] Plutino, A. (2017). Teachers as awakeners: a collaborative approach in language learning and social media. In C. Alvarez-Mayo, A. Gallagher-Brett, \& F. Michel (Eds), Innovative Language Teaching and Learning at University: Enhancing Employability , 115-125.

[17] Porter, D \& Roberts, J. (1987). Authentic listening activities. In Long, M H \& Richards, J C (eds.), Methodology in TESOL-A book of readings, Newbury House, New York, 177-187.

[18] Qian Min-xian, Yuan Zhou-min, Fang, Zong-xiang. (2010), Research on English listening teaching in network environment. Journal of Xi'an International Studies University, 48(4), 80-83.

[19] Reinders, H., \& White, C. (2011). Special issue commentary: Learner autonomy and new learning environments. Language Learning and Technology, 15(3), 1-3.

[20] Shu Ding-fang. (2006). Towards a new model of classroom instruction in foreign language teaching. Foreign Language World, 4, 21-29.

[21] Tomlinson, B \& Whittaker, C. (2013). Blended learning English language teaching. British Council.

[22] Vandergrift, L \& Goh, C. (2012). Teaching and Learning Second Language Listening: Metacognition in Action. Routledge, New York.

[23] Vandergrift, L. (1999). Facilitating second language listening comprehension: acquiring successful strategies. ELT Journal, 53(3), $168-176$

[24] Vygotsky, L. S. (1978). Mind in society: The development of higher psychological processes. Harvard University Press, Cambridge, MA.

[25] Wang Du-qin. (2002). Theories on English teaching. Foreign Language Teaching and Research Press, Beijing.

[26] Warschauer, M., \& Kern, R. (Eds.). (2000). Network-based language teaching: Concepts and practice. Cambridge University Press, Cambridge.

[27] Yan Can-xun (2005). A probe into the teaching of college English listening. Foreign Languages in China, 2, 56-60.

[28] Yin Jing-shu, FuYu-ling. (2007). An empirical research into scaffolding instruction of online college English listening. Journal of Zhejiang Ocean University (Humanity Science), 24(3), 107-112, 122. 